\title{
NEW CHALLENGES FOR SOCIAL POLICIES IN HEALTH CARE IN CROATIA IN LIGHT OF COVID-19 PANDEMIC
}

Social policies in the area of access to health care have been high on the agenda of the European Union which continuously monitors the state of healthcare in its Member States, particularly following the introduction of European Pillar of Social Rights with healthcare being one of the key areas of its Social Protection and Inclusion. Social policies in the area of access to healthcare have to deal not only with direct access to health care providers, but also with gender, age and education related disparities in access to healthcare, indirect and sometimes invisible causes of health disparities and social disparities leading to lower life expectancy.

In the times of the pandemic, it becomes clear that countries cannot successfully tackle the fight against communicable diseases without having sound social policies dealing with access to healthcare. During the corona virus public health crisis, new challenges to access to healthcare emerged, such as rapid digitalization of health care and introduction of telemedicine and obstacles in access to reproductive healthcare and immunization for children.

The paper provides an analysis of the main obstacles to effective access to health care in Croatia during the Covid-19 crisis, including access to reproductive health care, immunization for children and prevention of mortality, since Croatia is among the five EU Member States with the lowest cancer survival rate and has a shorter life expectancy by 2,9 years than the rest of the EU. We looked into the comparative health care policies of Sweden and the UK and analysed the most recent case law of the European Court of Human Rights in the area of access to reproductive health care that will shape all future discussions on social policies in health care. The purpose of this paper is to contribute to possible and much needed development of social policy in health care in Croatia.

Keywords: social policies, reproductive health, Covid-19.

${ }^{*} \mathrm{PhD}$, Assistant Professor, Department of Labor and Social Law and Social Work, Faculty of Law, University Josip Juraj Strossmayer, Osijek, Croatia. Email: hspadina@pravos.hr. 


\section{INTRODUCTION}

Social policies in the area of health care areone of the most important pillars of development in modern societies. Advanced social policies must have three angles: formulation of health policies, development of sound strategies for protection of public health care and protection of particularly health-vulnerable individuals (children, elderly, persons with chronic illnesses, oncology patients).

States have an obligation to respect and allow the right to access to health care, an obligation to protect and to prevent impediments to health care access, and an obligation to fulfil legal obligations in providing a legal framework for non-discriminatory health care. Without state involvement in the development of sound and well-planned health policies, we cannot hope for long life expectancy, healthy life and low risks from chronic and communicable diseases (cf. Deaton, 2002, 2013; Bambra, 2005, 2016, Whitehead, 2001). Health policies alone cannot guarantee the best health outcomes and one cannot neglect the influence of other relevant factors such as behavioural impacts to good health, as well as genetic, environmental, economic, sanitary and water factors, income levels and social wellbeing (Hill, Irving, 2020, p.140). We support the view of Hill and Irving that "the maintenance of good health depends upon a combination of protection from risks provided by public policies other than medicine, as well as the decisions people take for themselves" (Hill, Irving, 2020, p.142).

By evaluation of the ICESCR General Comment No. 14, the right to health must include four criteria:

- availability (the functioning of public health and health-care facilities, goods and services, as well as programmes, which have to be available in sufficient quantity);

- accessibility of facilities, goods and services, for health requires non-discrimination, physical accessibility, affordability and the adequate information;

- acceptability (all health facilities, goods and services must be respectful of medical ethics and culturally appropriate, sensitive to gender and life-cycle requirements, as well as designed to respect confidentiality and improve health and the health status of those concerned) and

- quality (health facilities, goods and services must be scientifically and medically appropriate and of good quality) (ETC, 2012, p.152).

\section{THE RIGHT TO HEALTH AND ITS IMPACT OF HEALTH CARE SOCIAL POLICIES}

The right to health has been recognized as a fundamental human right since the inception of international human rights legal framework. The Constitution of the World Health Organization defined health for the first timein 1946, and two years later provisions of 1948 Universal Declaration of Human Rights reinforced health as a fundamental human right ("Everyone has the right to a standard of living adequate for the health and well-being of himself and his family..."). All subsequent legal fundamental rights instruments were 
very clear that health is a precondition for all other rights and the main source of possible inequalities and discrimination. This is further highlighted by the notion that health is closely linked to all other human rights and cannot be defined independently from other human rights, as shown in next graph:

Graph 1 Examples of links between health and human rights

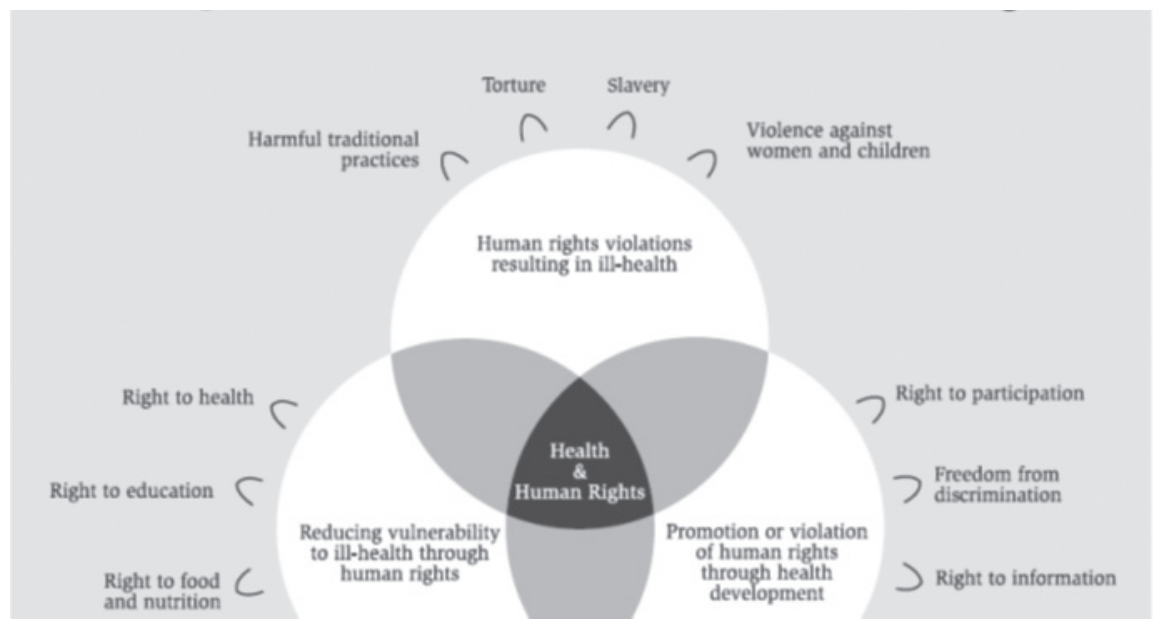

Source: ETC, Understanding Human Rights, Manual on Human Rights Education, 2012, p. 149.

Therefore, we should not approach the creation of healthcare social policies from a one-dimensional perspective, but should always bear in mind that creation of healthcare policies must be approached from a broader angle and taking into consideration multitude of factors and possible impact to other human rights. Particularly important for public health policies is the notion expressed in the above graph, that we can significantly reduce vulnerability to ill-health by respecting other human rights. Unless we have this in mind when designing health care policies, they could lead to further social exclusion and creation of new forms of inequalities and discrimination. In the current times, we can already see how health care policies did not target all the individuals at risk prior to the pandemic. A new study conducted showed that corona virus infection rates were significantly higher among children of minorities and those of a lower socioeconomic status. The study examined 1,000 child patients tested between March 21 and April 282020 in Washington DC, USA. Only $7.3 \%$ of white children tested positive for corona virus, in contrast to $30 \%$ of African-American children and $46.4 \%$ of Hispanic children. Three times as many African-American children reported known exposure to the virus than white children, the researchers reported in the journal Paediatrics (CNN, 2020). The report concluded that inequalities could stem in part from limited access to health care and resources, as well as bias and discrimination. "Understanding and addressing the root causes of these disparities are needed to mitigate the spread of infection," the researchers wrote (CNN, 2020). 
Over 3 billion people do not have access to basic hand-washing facilities, over 1.5 billion children are out of schools during the current pandemic and many will never return to schooling due to poverty and early child marriages, $32 \%$ of children worldwide who show symptoms of pneumonia are not being cared for by a health provider (UNICEF, 2020, p. xvi, cf. Bambra, 2016), so it is not difficult to envision the possible outcomes of health disparities for vulnerable individuals, primarily children, during and after the pandemic. The latest report by the UN Secretary-General Every Women, Every Child movement, underlined that efforts to contain Covid-19 have frequently resulted in disruptions to the delivery of essential services, putting women, children, and adolescents at a higher risk of death, disease, and disability from preventable and treatable causes. Some of the most severely impacted services have been routine immunisation services, malaria bed net distribution campaigns, family planning and antenatal care services (UNICEF, 2020, p. xix). In order to mitigate the negative impact of public health care emergencies, we need to focus on developing new well-elaborated, targeted social policies in access to healthcare.

\section{SOCIAL POLICIES ON ACCESS TO REPRODUCTIVE HEALTH CARE}

The latest report by the United Nations alerts to disruptions in meeting family planning needs due to the C-19 lockdown, which seriously affected the ability of women to get access to reproductive health care and to prevent unintended pregnancies. Estimated 47 million women were unable to use contraceptives out of 450 million women who had been using them prior to the COVID-19 pandemic (UNPFA, 2020). Difficulties ranged from medical staff being unable to provide services, closure of health facilities, fears of COVID-19 exposure or due to movement restrictions, leading to women refraining from visiting healthcare facilities, supply chain disruptions limiting availability of contraceptives, women being unable to use their preferred method of contraception, and instead using a less effective short-term method, or discontinuing contraceptive use entirely. UNFPA estimated that for every 3 months of the C-19 lockdown, assuming high levels of disruption, up to 2 million women may be unable to use modern contraceptives and if the lockdown continues for 6 months, an additional 7 million unintended pregnancies are expected to occur. Without mitigation strategies, depending on the degree that health services are disrupted and the duration of these disruptions, it is estimated that between 13 million and 51 million women who otherwise would have used modern contraceptives, will be unable to prevent unintended pregnancies (UNFPA, 2020, p.1).

In Croatia, we still do not have sufficient research data on the availability of family planning services and contraceptives during Covid-19 lockdown, so it is very difficult to assess whether women had access to reproductive health care. We do have recent data on the use of primary reproductive health care facilities by women, showing a steep decline of more than $40 \%$ in the use of reproductive health services during lockdown compared to previous year. This decline should be a call for urgent changes in health care policies, as it might have very serious consequences to reproductive health of women in Croatia and might lead to disruptions in taking contraceptives, as well as regular medical check-ups. 
Graph 3, Comparison of frequency of contacts with primary health care providers of reproductive care for women in first five months of 2019 and 2020.

Translation of terms: Left side of the table: Number of health care visits; First row of the bottom of the table: January, February, March, April May; Second row of the bottom of the table: Year 2019, 2020.

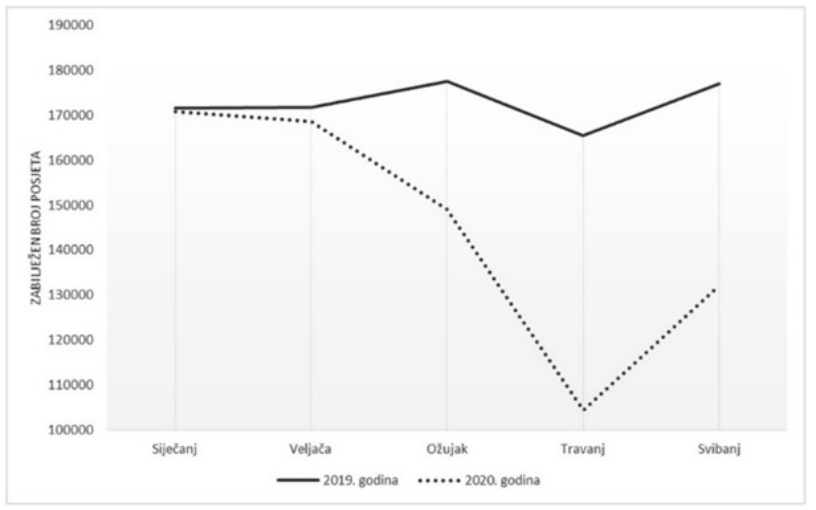

Source: Croatian Institute for Public Health, September 2020.

In such circumstances, increase of unintended pregnancies, higher rate of sexually transmitted diseases, higher health risks and worse outcomes of curable reproductive system diseases might be a direct result of women being unable to access reproductive health care providers. It is particularly concerning that the relevant Ministry of Health did not publish any public documents on the access to reproductive health care during the Covid-19 pandemic; nor did it provide guidance to women on how to obtain reproductive healthcare services during lockdown. Women were left to deal with their reproductive health issues individually with their gynaecologists and so far, we do not have relevant information whether gynaecologists were available for on-line appointments or whether they were flexible enough to ensure maximum possible capacity of healthcare.

Having in mind that on 31 December 2019, Croatian healthcare providers were lacking 61 gynaecological teams (Ombudsperson for Gender Equality, 2020, p.271), we cannot be overly optimistic on the availability of reproductive health care to women in Croatia during the pandemic. In addition to this, prior to the pandemic, $59 \%$ of licensed medical staff in Croatia refused to assist in abortions due to their religious faith and conscience (Ombudsperson for Gender Equality, 2020, p. 269), extending this even to pharmacists who refused to provide contraceptive pills to women with medical prescriptions. In April 2020, the non-Governmental organization Platform for Reproductive Justice conducted research on the availability of abortions during lockdown and results showed unavailability of abortion in 8 out of 29 hospitals, 6 being public hospitals covering large territorial areas of the country (Platform for Reproductive Justice, 2020). Refusal to perform abortion on grounds of religious faith was explicitly dismissed by the European Court of Human Rights in decision Linda Steen v. Sweden (Application no. 62309/17 Linda STEEN against Sweden of 11 February 2020). The Court pursued the legitimate aim of protecting the health of women seeking abortion; observing that Sweden provides nationwide abortion services 
and therefore has a positive obligation to organise its health system in a way that ensures the effective exercise of freedom of conscience of health professionals in the professional context does not prevent the provision of such services (ECtHR, 2020). This decision might have long-reaching consequences regarding all practices of refusal to perform legally allowed abortions and will probably have significant impact on reproductive health care policies in all countries where the right to religious beliefs precedes the right to safe medical service of termination of pregnancy.

Unavailability of public reproductive health care services directly affects the ability of women to achieve gender equality and to participate in all spheres of private and public life (Ombudsperson for Gender Equality, 2020, p. 272), but it also represents one of the worst violations of fundamental human rights because it forces women to seek illegal services which might jeopardize their health and might end up with fatal consequences. Therefore, sound and well-planned reproductive health care policies are necessary, particularly in times of public health emergencies, like a pandemic, where women suffer disproportionate discrimination if those policies do not provide them with uninterrupted health care.

One of the consequences of the pandemic lockdown to reproductive health care services was the unavailability of in-vitro fertilisation procedures. The most recent survey done by Croatian non-Governmental organization RODA showed that spring lockdown resulted in 47 days to two months unavailability of in-vitro fertilisation procedures. This led to a decrease of $60-70 \%$ of in vitro procedures during a three-month period (between March and June 2020), which might result in an estimated decline of 200 pregnancies. As this estimate is only based on official data from public hospitals, the amounts have to be doubled to account for a decline in private clinics (RODA, 2020). Despite the public health emergency, the Ministry of Health did not provide any guidance on in-vitro procedures during lockdown.

Another concerning aspect from the point of view of social policies is the continued deterioration of antenatal and postnatal health services. Research by RODA showed that delivery and breast feeding training were cut down by $56 \%$ during C- 19 lockdown, with $79 \%$ of pregnant women attending on-line training. Particularly concerning is the finding that $68,4 \%$ of pregnant women were not contacted by field nurses during lockdown, nor were they informed about the availability of such a service. Pregnancy health care during the pandemic lockdown was downsized in public health centres (a survey demonstrated that $9 \%$ of pregnant women did not have regular medical check-ups during lockdown) which referred pregnant women to private clinics(RODA, 2020).Pregnant women who were admitted to public health facilities were required to provide protective equipment themselves (50\%), while $34 \%$ had to ensure permits to travel to other regions due to the unavailability of health centres in their place of residence. Prior to the lockdown, $62 \%$ of women in Croatia had a birth partner in the delivery room, while during C-19 that number went down to only $21 \%$, causing women to have worse experiences with delivery than with a birth partner. This was practised despite the recommendations of the World Health Organization that there is no reason to deny the right to a birth partner during Covid-19 pandemic (RODA, 2020). Other novelty issues relevant for social policies in healthcare are the inability to move after delivery, the duty of patients to wear a face mask during 
delivery (31\%), and only $36,38 \%$ mothers not being separated from their babies which then led to only $41,32 \%$ of breastfed babies at hospitals during lockdown. RODA warned that such practices are shifting child-friendly policies in Croatian hospitals in the opposite direction. Survey data demonstrates an urgent need to adopt a national breastfeeding plan in crisis situations, but also a need to develop more targeted support for vulnerable groups, among which the most vulnerable are women and children living in the rural parts of the country (RODA, 2020).

If we are to look for positive examples on how to successfully develop reproductive health care policy in times of public health emergencies like the current Covid-19 crisis, we can use the example of the British National Health Service (NHS) which on its web site clearly specifies what women can expect from reproductive health care providers during the pandemic. Access to health care services is fully ensured and the NHS underlines that all pregnant women still had regular appointments and scans, but with adjustments like the possibility of midwife appointments being online, over the phone or video call, the duty to wear a mask or gown and a possibility of rescheduling appointments. The NHS highlights the importance of having a midwife present during delivery to keep the woman and the baby safe, thus completely supporting the idea of delivery at home if the mother and the baby are well. Other possibilities are delivery in a midwifery-led unit or in a birth centre in case of complicated pregnancies or corona virus infection of the mother. The NHS also promotes a health policy of having a birth partner if they do not have the symptoms of corona virus, recognizing how important a birth partner is for the safety of pregnant women and wellbeing during labour and birth (NHS, 2020). In the case of a corona virus infection of a planned birth partner, the NHS provides alternative options to women by stipulating a policy in which they should choose a backup birth partner. Finally, the NHS is very supportive of breastfeeding and encourages all women to breastfeed, as "there is no evidence corona virus can be passed on to babies in breast milk, so the benefits of breastfeeding and the protection it offers outweigh any risks." This reproductive health policy can serve as an example of a sound, targeted and comprehensive social policy. The NHS took into consideration a variety of possible issues related to pregnancy and COVID-19 and provided detailed, easy to understand guidance on the access to health care. It is very likely that provision of reproductive health care services in the UK was uninterrupted during the pandemic as it should have been in other countries as well and that women will not suffer health consequences of non-existent health policies where the authorities simply ignored the fact that reproductive health care cannot be put on hold even in public health emergencies.

\section{PREVENTION OF MORTALITY THROUGH IMPROVED HEALTH CARE POLICIES}

Due to insufficient inter-sectoral health policies for removal of the main causes for poor health, which contribute to the high mortality rates from diseases that could have been prevented and cured, along with poor health care quality, Croatian life expectancy is 2,9 years shorter than the rest of the EU (OECD, 2020). Croatia is in the $4^{\text {th }}$ place in the 
world for mortality from colon cancer, in the $8^{\text {th }}$ place in the world for mortality from lung cancer ( $3^{\text {rd }}$ in the EU) and in the $23^{\text {rd }}$ place in the world for breast cancer (Index, 2020).

Taking into consideration that the average waiting time for the medical scans related to the possibility of early detection of cancer is one year, if the doctor does not suspect cancer and does not refer the patient for urgent procedure, (Ombudsperson, 2020); we can clearly notice the link between inadequate health care policies and fatal health outcomes. Despite having an alarming curable cancer mortality rate, Croatia still does not have a national plan for prevention of cancer, nor coherent strategy on early detection. It is very difficult to understand why the EU Member State did not adopt a strategic plan formulating health care policy for such an important area, as it is removal of the main causes for cancer mortality. According to the European Commission survey, the most prominent causes of lung and colon cancer are widespread smoking (Croatia holds the $3^{\text {rd }}$ place in the EU among female and teenage smokers) and poor nutrition (in 2017, every fifth adult was obese, with a significant increase in obesity rates among children).

Cancer is currently detected through routine check-ups inonly $6 \%$ of cases, while in $72 \%$ of cases it is detected upon the patient's explicit request (House of Human Rights, 2020). The same report identifies insufficient radiological capacity of health care providers, unequal territorial access for cancer patients and the lack of relevant information as the main issues undermining quality healthcare and higher positive outcomes for cancer patients. In addition to the already existing healthcare gaps in treatment of cancer, the current Covid-19 pandemic adds a new layer of problems. The Chief of the Oncology Department of the Clinical Centre Split gave a TV interview in September in which he presented a survey conducted to analyse the number of newly diagnosed breast cancer patients in Croatia during lockdown. The results showed that in the first two weeks of May, the number of newly diagnosed breast cancer patients was almost $50 \%$ lower than in first two weeks of 2019, despite the continued increase of breast cancer rates and a failure to diagnose breast cancer will lead to later detection and worse health outcomes (Slobodna Dalmacija, 2020). The doctor presented data showing that only $20 \%$ of patients get an early detection of colon cancer and approximately $65 \%$ of women get an early detection of breast cancer. The number of coronavirus patients was almost the same as the number of newly diagnosed cancer patients, but mortality rates are vastly different because 203 persons died of coronavirus, while 6000-7000 persons died of cancer. Still, it seems that health care authorities did not consider it necessary to work urgently to develop health care policies, expand existing cancer care capacities and work collaboratively with all relevant actors to reduce cancer incidence and to prevent negative health outcomes of all curable cancers.

Sweden is a good example of a well-organised network of specialized centres along with advanced cancer policies and strategy documents, a strategy to reduce the burden of tobacco use, as well as obesity and physical inactivity. Sweden's National Board of Health and Welfare has recommended national screening programmes for cervical cancer, colorectal cancer, breast cancer and 25 congenital diseases for newborn children, leaving it to each health-care region to decide whether to implement the programme (WHO, 2020). 


\section{IMMUNIZATION RATES AS INDICATOR OF HEALTH CARE POLICIES}

Vaccination is a human right, underpinning global health security as a vital tool in the battle against antimicrobial resistance (WHO, 2020b). Vaccines reduce risks of getting20 life-threatening diseases and preventing 2-3 million deaths every year from diseases like diphtheria, tetanus, pertussis, influenza and measles by working with the body's natural defences to build protection. (WHO, 2020b)

Only $86 \%$ of children worldwide received the three necessary doses of the DPT3 vaccine in 2019, while preliminary data for the first four months of 2020 points to a substantial drop in the number of children completing three doses of the vaccine against DTP3 which is the first time in 28 years that the world may see a reduction in DTP3 coverage due to disruptions in the delivery and uptake of immunization services caused by COVID-19 (WHO, 2020d).

Prior to the corona virus, Croatia generally had low vaccination rates in adults and children. Only $21 \%$ of adults older than 65 in 2016got the flu vaccine, only half of the EU average (of 44\%) and far below the WHO recommended vaccination rate of 75\%. (OECD, 2020 , p. 14). Despite the fact that immunization is obligatory for all children, $93 \%$ of children were vaccinated against diphtheria, tetanus and pertussis (DPT3) and measles, thus not achieving collective immunity for which a vaccination rate of $95 \%$ is required (OECD, 2020, p. 14).

Low vaccination rates in Croatia did not trigger further development of health care policies(OECD, 2020, p. 14) which would target public awareness and would introduce specific measures of promoting benefits of specific vaccinations for elderly population, children and all other vulnerable categories. Developing collective immunity is particularly topical with the outbreak of the new corona virus, as countries around the globe will have to adopt new health policies on vaccinating vulnerable groups to prevent and control ongoing and future infectious disease outbreaks. In these circumstances, health policies can use the opportunity to develop measures aimed at the advancement of current vaccination rates, since one of the most important goals in current public healthcare is to strengthen the human immunity to be able to fight already existing and new viruses and to reduce mortality rates of C-19.

\section{DIGITALISATION OF HEALTH CARE DURING CORONA VIRUS HEALTH CRISIS}

The Croatian healthcare system had been trying to introduce digitalisation of healthcare services for at least the past decade, but it never managed to fully do so. This was partially due to the widespread resistance from various sides involved in the idea to digitalize one part of health services where direct contact between medical staff and patients was not necessary. Digitalisation was difficult to imagine in a country where only $35 \%$ of the population had above basic digital skills in 2019 (Skills Panorama, 2020). The only part of the health system where certain progress in digitalisation has been made was the introduction of electronic prescriptions directly submitted by medical doctors to 
pharmacies. E-prescriptions now form $80 \%$ of all prescriptions in Croatian pharmacies (OECD, 2020, p.21). E-appointments aimed at achieving more transparency with specialist appointments in hospitals and health centres through the website showing the availability of certain medical services, but this had very limited success due to the cost of travel to other cities for specialist scans and thus, inability of patients to afford use of health services. We can say that the Croatian health system did not further progress from e-prescriptions until the corona virus outbreak when digitalisation of the majority of health services was suddenly introduced as a matter of necessity in the provision of healthcare in public health emergencies. This was done without any particular health policy change or guidance by the relevant Ministry of Health, so we had an unusual situation in which healthcare policy followed practical implementation. Patients, particularly elderly and chronic patients, were satisfied with the unexpected introduction of digitalisation and availability of telemedicine for certain health needs because they were not required to personally go to health centres for minor health issues like prescriptions of chronic illness medications or simple consultations. It remains to be seen whether the authorities will accept transformative changes brought about by C-19 and formulate health policies incorporating best practices in digitalisation of health services and telemedicine during the $\mathrm{C}-19$ outbreak. If this does not happen, we cannot expect any digital progress in health care.

\section{CONCLUSION}

The Corona virus pandemic is currently changing all aspects of our lives, with profound changes in sectors of healthcare and education. Some new developments seriously undermined previously achieved standards and levels of healthcare (like the inability to conduct child immunisations, restricted access to reproductive health care services or limited availability of early cancer detection), but many Covid-19-related changes can also be a transformative force in healthcare. This is primarily related to the sudden and widespread introduction of digitalisation of healthcare services and the availability of telemedicine consultations, which might significantly reduce social disparities and remove all obstacles to access to healthcare if they are related to travel costs or unavailability of specialist medical staff in certain remote regions. Healthcare policies are usually not formed during public health emergencies, but in this case, we can use the ongoing emergency to learn more about the importance of uninterrupted and widely available reproductive healthcare, as interruptions might lead to fatal outcomes of sexually transmitted diseases or illegally performed abortions if safe ones are unavailable. We also learned that child-friendly policies in delivery rooms primarily related to breastfeeding, presence of birth partner and contact between mother and baby should never be suspended without strong medical arguments. The Covid health crisis can also provide valuable contributions to the development of targeted and very specific cancer detection programmes, which could start as early as at birth like in Sweden. Cancer prevention healthcare policies should not neglect the crucial impact of nutrition, smoking, alcohol consumption and physical activity on the development of 
certain types of cancer and should reflect measures to decrease poor food choices and fight obesity, closely linked not only to several different cancers, but also diabetes and cardio-vascular diseases.

With over 33 million people infected and over one million deaths from corona virus, we might even stop questioning vaccination efforts and start developing health care policies to promote vaccination as much as possible and as early as possible whenever vaccines are sufficiently tested and medically approved. 


\section{LIST OF REFERENCES}

Bambra, C. 2005. Worlds of Welfare and the Health Care Discrepancy. Social Policy ad Society, 4(1):31-41.

Bambra, C. 2016. Health Divides: Where You Live Can Kill You. Bristol. Policy Press.

CNN.Infection rates are significantly higher for minority and low-income children, study finds. Article published on 5 August 2020.Available at:https://edition.cnn.com/world/live-news/ coronavirus-pandemic-08-05-20-intl/h_1b5968cefe9e57429550f5550492cd06(20.09.2020).

Croatian Public Health Institute (Hrvatskizavod za javnozdravstvo) (HZJZ). Use of primary health care facilities during pandemic of COVID-19 in Republic of Croatia published 23 September 2020. Available at:https://www.hzjz.hr/sluzba-javno-zdravstvo/ koristenje-primarne-zdravstvene-zastite-u-vrijeme-epidemije-covid-19-u-republicihrvatskoj/(20.09.2020).

Deaton, A. 2002. Policy Implications of the Gradient of Health and Wealth, Health Affairs, 21: $13-30$.

Deaton, A. 2013. The Great Escape: Health, Wealth and the Origin of Inequality. Princeton. New York. Princeton University Press.

European Court of Human Rights, Application no. 62309/17 Linda STEEN against Sweden of 11 February 2020.https://hudoc.echr.coe.int/fre\#\{“itemid”:[“001-201732”]\}(20.09.2020).

Hill, M.Irving, Z.2020. Exploring the World of Social Policy: An International Approach. UK.Policy Press. University of Bristol.

Hunter, D. 2003. Public Health Policy. Cambridge. Polity Press.

Index.hr, news portal, https://www.index.hr/vijesti/clanak/hrvatska-je-u-svjetskom-vrhupo-raku-debelog-crijeva-ovo-su-glavni-razlozi-za-to/2184502.aspx (30.09.2020)

NHS. National Health Service.UK.Available at:https://www.nhs.uk/conditions/coronaviruscovid-19/people-at-higher-risk/pregnancy-and-coronavirus/(20.09.2020).

OECD/European Observatory on Health System and Policies. 2019. State of Health in the EU, Hrvatska: Pregledstanjazdravljaizdravstvenezaštite2019.OECD Publishing, Paris/ European Observatory on Health System and Policies. BrusselsAvailable at:https://read. oecd-ilibrary.org/social-issues-migration-health/hrvatska-pregled-stanja-zdravlja-izdravstvene-zastite-2019_df8b2178-hr\#page1(10.09.2020).

Ombudsperson for Gender Equality.2020. Annual Report for 2019. Zagreb.Available at:https://www.prs.hr/index.php/izvjesca/2019(14.09.2020).

Ombudswoman of the Republic of Croatia.2020. Annual Report for 2019. Zagreb, Available at:https://www.ombudsman.hr/hr/izvjesca-puckog-pravobranitelja/(14.09.2020).

Platform for Reproductive Justice research published on 28 April 2020. Available at:https:// www.reproduktivna-pravda.hr/2020/04/28/mi-to-ne-radimo-pobacaj-u-hrvatskoj- 
nedostupan-i-skup-a-do-informacija-se-tesko-dolazi/(14.09.2020).

RODA, Results of Survey on Availability of Health Care for Women during Pandemic COVID-19. 2020.Available at:https://www.roda.hr/udruga/projekti/zagovaranje-za-zdravstvenu-skrbzena-temeljenu-na-dokazima-u-doba-pandemije-covid-19/rezultati-istrazivanja-dostupnostzdravstvene-skrbi-zena-tijekom-pandemije-covid-19.html(15.09.2020).

Skills Panorama. European Commission. 2020. Croatia: Key Facts. Available at: https:// skillspanorama.cedefop.europa.eu/en/countries/croatia(20.09.2020).

Slobodna Dalmacija, Oncologist EduardVrdoljakwarns of concerning statistics: Coronavirus did not save us from cancer; Covid caused mortality of 203 people, cancer caused mortality of six to seven thousand patients, newspaper article based on TV interview published on 9 September 2020,Available at:https://slobodnadalmacija.hr/vijesti/ hrvatska/onkolog-eduard-vrdoljak-donosi-zabrinjavajuce-brojke-korona-nas-nijespasila-od-raka-od-covida-je-umrlo-203-ljudi-a-od-raka-sest-do-sedam-tisuca1043236(20.09.2020).

Spicker, P. 2014. Social Policy, Theory and Practice. UK Policy Press. University of Bristol.

UNFPA, Impact of the COVID-19 pandemic on family planning and ending gender-based violence, female genital mutilation and child marriage: pandemic threatens achievement of the transformative results committed to by UNFPA. Interim Technical Note. New York. 2020.Available at:https://www.unfpa.org/resources/impact-covid-19-pandemicfamily-planning-and-ending-gender-based-violence-female-genital(10.09.2020).

UNICEF, WHO, UNFPA, GFF. 2020. Every Woman Every Child.Available at:https:// reliefweb.int/sites/reliefweb.int/files/resources/2020-Progress-Report-on-the-EWECGlobal-Strategy.pdf(15.09.2020).

Whitehead, M. Dahlgren, G. Gilson, L. 2001. Developing the Policy Response to Inequalities in Health: A Global Perspective, in Evans, T. Whitehead, M. Diderichsen, F. Bhuiya, A. Wirth, M. (eds) Challenging Inequalities in Health: From Ethics to Action. Oxford. Oxford University Press.

WHO 2020 a.World Health Organization Regional Office for Europe.Sweden's health authorities streamline health screening programmes. Available at:https://www.euro.who. int/en/countries/sweden/news/news/2020/2/swedens-health-authorities-streamlinehealth-screening-programmes(17.09.2020).

WHO. 2020b Available at: https://www.who.int/health-topics/vaccines-and-immunization?gc lid=EAIaIQobChMI8fubk96J7AIVj9iyCh3h1AzEEAAYASAAEgIm4vD_BwE\#tab=tab_1 (17.09.2020).

WHO. 2020c. Sweden Country profiles on cancer prevention, Available at: https://www. who.int/cancer/country-profiles/swe_en.pdf?ua=1(17.09.2020).

WHO. 2020d. Available at: https://www.who.int/news-room/detail/15-07-2020-whoand-unicef-warn-of-a-decline-in-vaccinations-during-covid-19(17.09.2020). 